Article

\title{
Cytotoxic Activity of Vernonia mespilifolia Less Used in the Folk Medicine in the Eastern Cape Province, South Africa
}

\author{
Medicinal Plants and Economic Development (MPED) Research Centre, \\ Department of Botany, University of Fort Hare, Alice 5700, South Africa; \\ unuofinjeremiah@gmail.com (J.O.U.); aafolayan@ufh.ac.za (A.J.A.) \\ * Correspondingence: gotunola@ufh.ac.za; Tel.: +27-40-602-2320
}

Jeremiah Oshiomame Unuofin, Gloria Aderonke Otunola * and Anthony Jide Afolayan

\begin{abstract}
Vernonia mespilifolia is widely used in folk medicine in the Eastern Cape Province, South Africa. The aim of this study was to evaluate the biological activity of the acetone, aqueous and ethanol extracts of Vernonia mespilifolia using brine shrimp hatchability and lethality assay. The result showed hatching success in this order: aqueous extract $(48.6 \%)>$ acetone extract $(38.2 \%)>$ ethanol extract $(26.8 \%)$. The $\mathrm{LC}_{50}$ of the lethality assay were in this order: acetone extract $(67.8 \mu \mathrm{g} / \mathrm{mL})>$ aqueous extract $(132 \mu \mathrm{g} / \mathrm{mL})>$ ethanol extract $(383 \mu \mathrm{g} / \mathrm{mL})$. According to Meyer's toxicity index (using brine shrimps), $\mathrm{LC}_{50}<1000 \mu \mathrm{g} / \mathrm{mL}$ is toxic. Therefore, the results of the three solvent extracts could be said to be toxic as do have $\mathrm{LC}_{50}<1000 \mu \mathrm{g} / \mathrm{mL}$. However, the toxicity of the crude extracts could suggest or confer some antitumor properties, hence further in vitro, in vivo and antitumour assays are recommended to further substantiate these claims.
\end{abstract}

Keyword: Vernonia mespilifolia; Artemia salina; toxicity; biological activity; hatchability; lethality

\section{Introduction}

The pivotal role medicinal plants and traditional health systems play in solving the health care problems of the world is gaining increasing attention. As a result of this rebirth of interest, research on medicinal plants is rising impressively at the international level, particularly developing countries where traditional medical practice is imbibed as an essential part of their culture [1]. Bioactive compounds present in medicinal plants are responsible for their efficacy [2]. These compounds are mainly secondary metabolites and they include alkaloids, essential oils, tannins and resins to mention a few, which function either in their original form or in semi-synthetic form [3]. In spite of these bioactive compounds exhibiting therapeutic potential, there is insufficient knowledge about their toxicogenic effects when consumed in large amount [4]. Many research studies at present focus on both pharmacology and toxicity of medicinal plants used by humans to promote safety with the use of plant products for the treatment of various ailments [5].

To this end, it is of great importance to verify the pharmacological qualities of herbalderived remedies and also their level of toxicity contrary to the putative view of the inocuity/inocuousness of natural products [6].

Various assays are being employed for the research of potential toxicity of herbal extracts based on different biological models, such as in vivo assays on laboratory animals. Brine Shrimp Lethality Assay (BSLA) has gained recognition as an alternative bioassay technique to screen the toxicity of algae [7], of dental materials [8], toxicity of heavy metals [9] and metal ions [10], toxicity of nanoparticles [11], as well as screening of marine natural products 
[12], the toxicity plant extracts $[13,14,15,16]$. It also indicates cytotoxicity of a myriad of pharmacological activities such as antimicrobial, antiviral, pesticidal and anti-tumor of compounds $[13,14]$.

Vernonia mespilifolia Less. popularly known as Uhlunguhlungu (Xhosa) among the indigenous people of the Nkonkobe Municipality of the Eastern Cape of South Africa is one of the five Southern African species of the Vernonia genus that is endemic or near-endemic to this subcontinent [17]. It is a climbing shrub that is $0.6-9.0 \mathrm{~m}$ tall, with pinnately-veined leaves, epaleate receptacle with obtuse involucral bracts, and white to violet florets [17]. Vernonia mespilifolia is commonly found in the Eastern Cape, Kwazulu-Natal, Limpopo, Mpumalanga and Western Cape provinces of South Africa [18]. It is used in the Eastern Cape of South Africa for ethno-medicinal management of weight loss and hypertension [19] and also for the treatment of heart water disease in goats [20].

Although $V$. mespilifolia is used for ethno-medicinal purposes there is limited knowledge about it toxicity level. This study aim to investigate the cytotoxic activity of the crude extracts of Vernonia mespilifolia using brine shrimp model.

\section{Materials and methods}

\subsection{Materials}

The whole plant parts used for this for this study was collected in June 2015 from its natural habitat in the wild at Zihlahleni Village Maipase, Nkonkobe Rural Eastern Cape, South Africa which lies at Latitude $32^{\circ} 51^{\prime} 41.846^{\prime \prime} \mathrm{S}$ and Longitude $27^{\circ} 10^{\prime} 59.318^{\prime \prime}$ E. The plant was authenticated by Mr. Tony Dold of Selmar Schonland Herbarium, Rhodes University, South Africa, and a voucher specimen (Unuofin Med, 2015/1) was prepared and deposited at the Giffen Herbarium, University of Fort Hare.

\subsection{Preparation of extracts}

The whole plant was rinsed with deionised water and gently blotted with paper towel to remove the water and subsequently oven-dried (LABOTEC, South Africa) at $55^{\circ} \mathrm{C}$ for 72 hours until constant weight was achieved. The dried sample was then ground into powder (Polymix ${ }^{\circledR}$ PX-MFC 90D Switzerland) and stored at $4{ }^{\circ} \mathrm{C}$ till needed for analyses. The ground sample (200g) was weighed into 3 separate conical flasks containing (2 L) acetone, ethanol, and water respectively and shaken in an orbital shaker (Orbital Incubator Shaker, Gallenkamp) for 48 hours. The crude extracts were filtered under pressure using a Buchner funnel and Whatman No. 1 filter paper. The acetone and ethanol extracts were further concentrated to dryness to remove the solvents under reduced pressure using a rotary evaporator (Strike 202 Steroglass, Italy), while the aqueous filtrate obtained was concentrated using a freeze dryer (Vir Tis benchtop K, Vir Tis Co., Gardiner, NY).

\subsection{A. salina hatching assay}

The method described by [21] was employed with little modifications. Five petri dishes containing $30 \mathrm{~mL}$ of the extracts were prepared in filtered sea water by dissolving them in minute amount of the parent solvents to yield a two-fold dilution of concentrations $(1,0.5$, $0.25,0.125$ and $0.0625 \mathrm{mg} / \mathrm{mL}$ ). A positive control was also prepared by dissolving potassium dichromate in seawater in the same concentrations as the plant extracts. Sea water alone was used as the negative control. The setup was allowed to stand for 30 minutes to allow the solvents to evaporate.

Ten (10) A. salina cysts were stocked in each of the petri dishes containing $30 \mathrm{~mL}$ of the prepared two-fold concentrations ( 1 to $0.0625 \mathrm{mg} / \mathrm{mL}$ ) of the plant fractions and positive 
control. The petri dishes were partly covered, incubated at $30^{\circ} \mathrm{C}$ and under constant illumination for 72 hours. The number of free nauplii in each petri dish was counted after every 24 hours till the end of 72 hours. The percentage of hatchability was calculated by comparing the number of hatched nauplii with the total number of cysts stocked.

\section{$2.4 \quad$ A. salina lethality assay}

A. salina cysts were hatched in sea water and 10 nauplii were pipetted into each petri dish containing the two-fold concentrations of the extracts and control as in the hatchability assay described above. The petri dishes were then examined and the number of living nauplii (that exhibited movement during several seconds of observation) was counted after every 24 hours and the set up was allowed to stand for 72 hours under constant illumination. The percentage of mortality (M \%) was calculated as: Mortality $(\%)=($ Total nauplii - Live nauplii $) \times 100 /$ Total nauplii.

\subsection{Data analysis}

The percentage hatchability success and mortality data obtained from the 5 different concentrations of each fraction and control experiments were used to construct the doseresponse curves. These were used to determine their corresponding $\mathrm{LC}_{50}$ values. The $\mathrm{LC}_{50}$ was taken as the concentration required for producing $50 \%$ mortality of the nauplii. $\mathrm{LC}_{50}$ values were determined from the best-fit line obtained by regression analysis of the percentage hatchability and lethality versus the concentration. The statistical analysis was done on MINITAB version 17 for Windows. One-way analysis of variance (ANOVA) followed by Fischer's Least Significant Difference (for means separation) was used to test the effect of concentration and time of exposure of the plant extracts on the hatchability success of the cysts and mortality of larvae respectively.

\subsection{Results and Discussion}

\subsection{Brine shrimp hatchability}

Brine shrimp hatchability test was used to determine the biological activity of Vernonia mespilifolia. The hatching success of A. salina incubated with different plant extracts and control is as shown in Figure. The sea water exhibited a significantly higher $(\mathrm{P}<0.05)$ hatching success $(71 \%)$ than the solvent extracts and the positive control (potassium dichromate) $(5.4 \%)$. The hatching success of the cysts in the acetone, aqueous and ethanol extracts were $38.2 \%, 48.6 \%$ and $26.8 \%$ respectively and were significantly different $(\mathrm{P}<$ $0.05)$ from each other. The hatching success of $A$. Salina cysts incubated with aqueous extracts had the highest hatching success and presumably least toxic of the solvent extracts used (Figure 1). This could explain why most traditional herbal medicines are prepared using water as a solvent because it is not or less toxic. This could also suggest why the cyst showed more resistant to hatching in the acetonic and ethanol extracts than in the aqueous extracts. This resistant could be attributed to the permeability barrier provided by the cysts [22, 23]. 


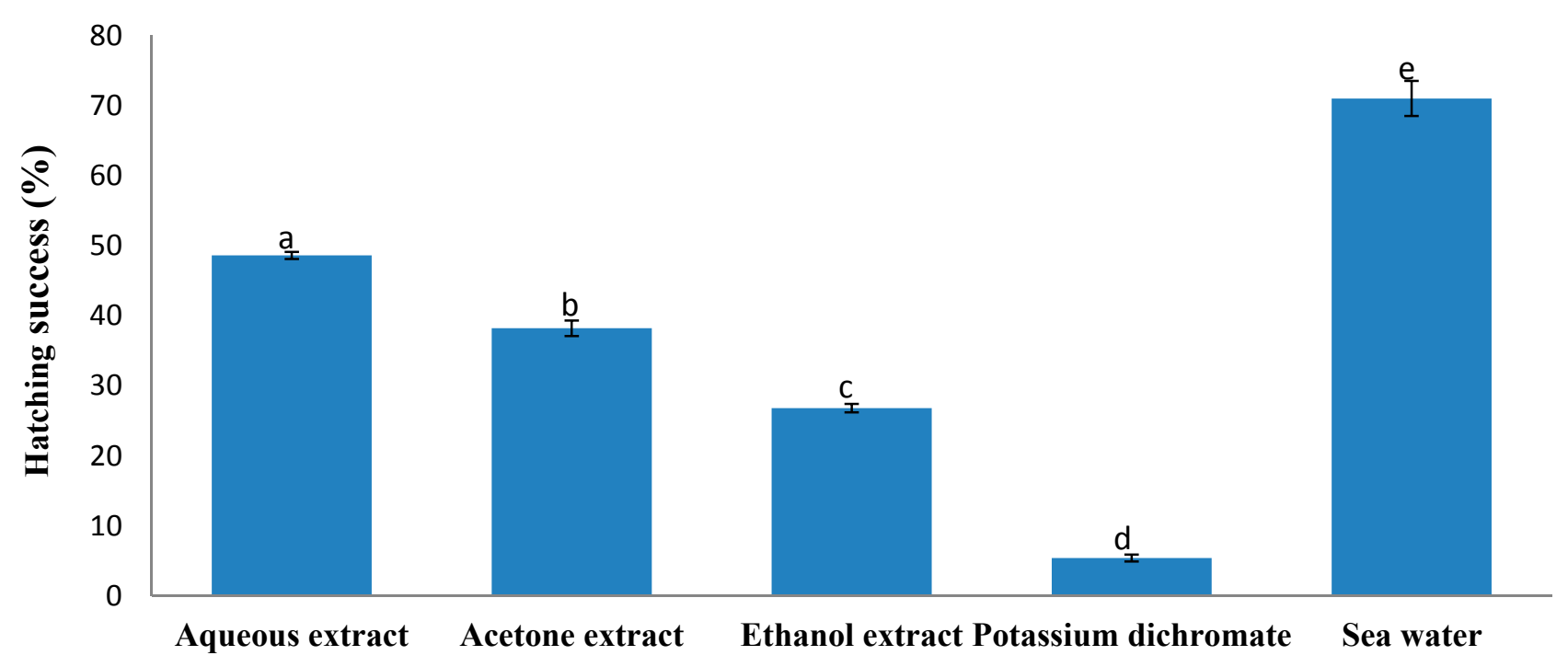

Figure 1: Percentage hatching success of $A$. salina cysts incubated in different solvent extracts and controls.

*The values are means of five concentrations for each plant extract/control \pm SD of three replicates. Bars with different letters are significantly different $(\mathrm{P}<0.05)$.

The A. salina embryos are highly defenseless to toxins at early developmental stages [24, 25, and 26]. In the brine shrimp hatchability assay, the hatching success significantly decreased with increasing concentrations of the crude extracts in a dose dependent manner. The hatching success of the cyst was also evaluated at different concentrations and the result is depicted in Figure 2. The aqueous extract exhibited its maximum hatching success at 0.5 $\mathrm{mg} / \mathrm{mL}(76 \%)$. The acetone and ethanol extracts had similar hatching pattern, with the highest hatching success observed at $0.125 \mathrm{mg} / \mathrm{mL}$ (Figure 2). The overall best percentage hatching success potential of cysts was observed with cyst incubated at $0.5 \mathrm{mg} / \mathrm{mL}$ in the aqueous extract which was significantly $(\mathrm{P}>0.05)$ greater when compared with other solvent used. Potassium dichromate showed the lowest hatching success. At $0.0625 \mathrm{mg} / \mathrm{mL}$, there was no significant difference in the hatching success of aqueous and potassium dichromate. There was also no significant difference in the hatching success of cysts incubated at 0.125 $\mathrm{mg} / \mathrm{mL}$ in both the aqueous and acetone extracts. The acetone and ethanol extracts had no significant difference in their hatching success at $0.25 \mathrm{mg} / \mathrm{mL}$. At concentrations of 0.25 $\mathrm{mg} / \mathrm{mL}-1 \mathrm{mg} / \mathrm{mL}$ for potassium dichromate, no hatching was observed. Also, cysts incubated in $1 \mathrm{mg} / \mathrm{mL}$ of acetone and ethanol extracts did not hatch. The inhibitory effect of Vernonia mespilifolia crude extracts could have attributed to the toxic compounds present in the extracts that have ovicidal property. Also reports have shown that secondary metabolites in plants could have effect on the embryonic development [27]. 


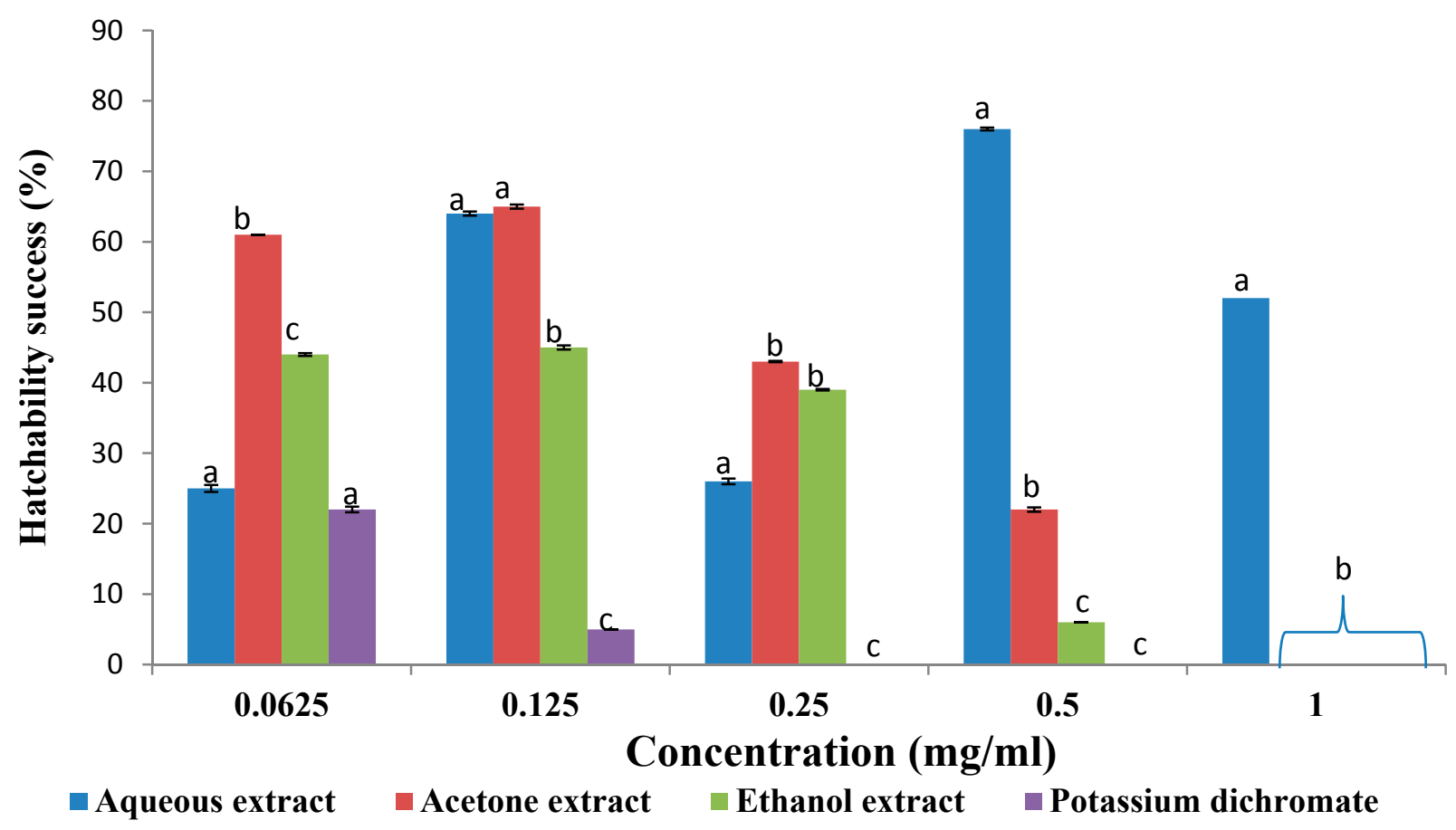

Figure 2: Effect of varying concentrations on hatching success (\%) of $A$. salina cysts.

*Values are means \pm SD of three replicates of the concentrations for each plant extract/control. Set of bars with different letters are significantly different $(\mathrm{P}>0.05)$.

The results of the effect of exposure time on hatchability showed that the sensitivity of $A$. salina cyst to the plant extracts was strongly dependent upon exposure period (Figure 3). A similar trend was observed with the aqueous and acetone extracts as there was significant differences in hatching success from $24 \mathrm{~h}$ to $48 \mathrm{~h}(\mathrm{P}>0.05)$. The lowest hatching success was observed after $24 \mathrm{~h}$ treatment in all the extracts. This result is in line with reports from [26, 27] which stated that $A$. salina is extremely susceptible to toxin during its early stage of development. The acetone and ethanol extracts experienced maximum hatching at $48 \mathrm{~h}$ with $45 \%$ and $32 \%$ hatching success respectively, after which death set in for the already hatched nauphlii. The aqueous extract had the highest hatching success at 60 hours. Also in Figure 3 there was a 1.3 and 1.1 fold decrease respectively in hatched cyst from 48 to $72 \mathrm{~h}$ in both acetone and ethanol extracts while aqueous extract decreased significantly by 1.1 fold after $60 \mathrm{~h}(\mathrm{P}<0.05)$. Sea water exhibited optimum hatching at $36 \mathrm{~h}$ and remained the same throughout the experiment. Cysts incubated in potassium dichromate decreased significantly by 3.5 -fold after 36 hours $(\mathrm{P}<0.05)$, followed by no hatching of cyst after 48 hours. 


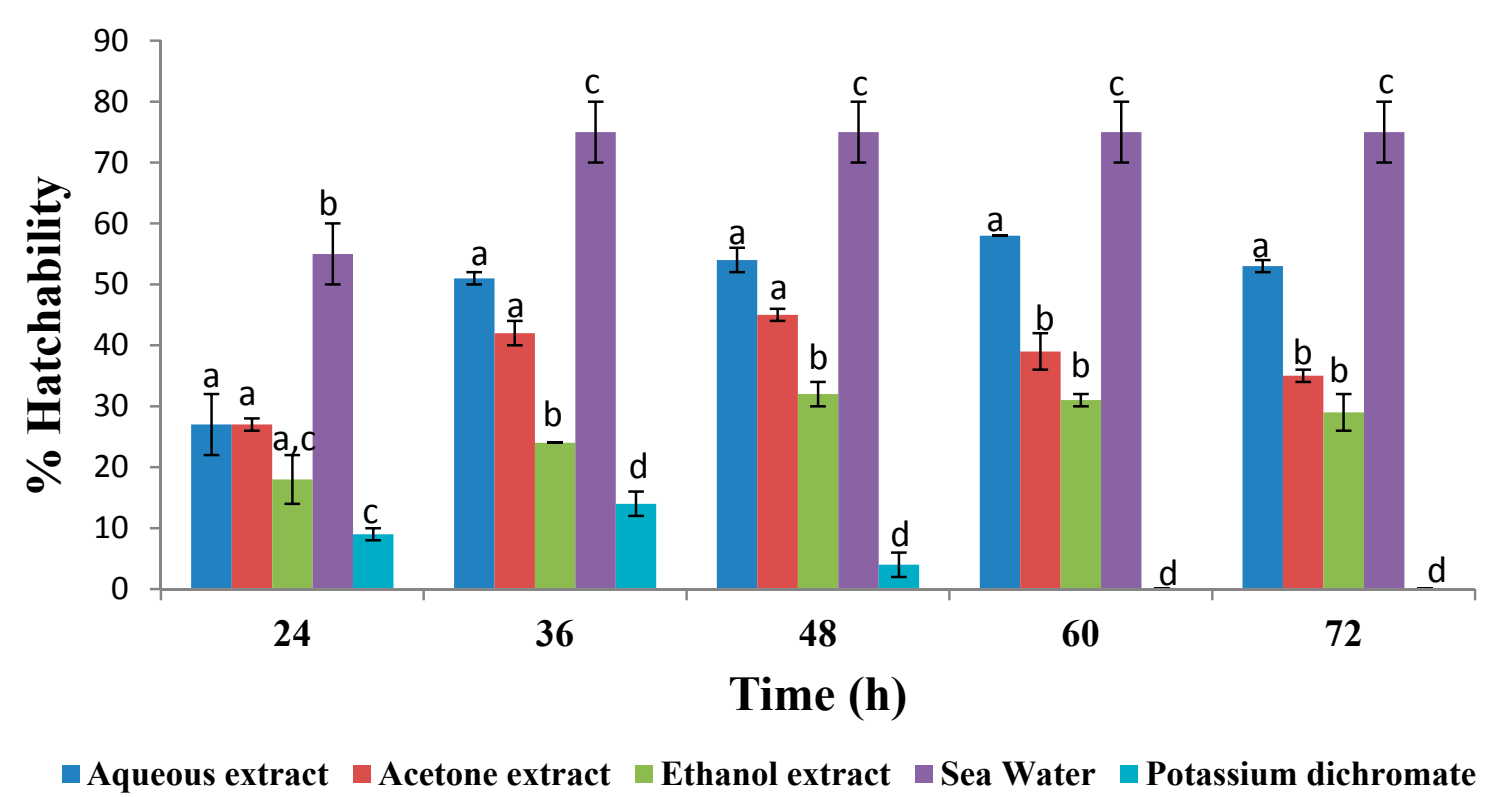

\section{Figure 3: Effect of time (h) on the hatching success of $\boldsymbol{A}$. salina cysts.}

*Values are means $\pm \mathrm{SD}$ of three replicates for each plant extract/control. Set of bars with different letters are significantly different $(\mathrm{P}<0.05)$.

\subsection{Brine shrimp lethality}

Brine shrimp cytotoxicity test is considered as a preliminary assessment of toxicity. This assay determines lethal concentration of active compounds such as heavy metals, pesticides, and medicines in brine medium $[28,29,30]$ and has been employed to determine toxicity of various active compounds because of it is reliable, rapid and very convenient to carry out [13, 31,21]. The percentage mortality of $A$. salina larvae (nauplii) incubated in different solvent extracts of Vernonia mespilifolia and controls are shown in Figure 4. There was high mortality of nauplii incubated in both the aqueous and acetonic extracts although there was no significant difference in their percentage mortality, whereas the nauplii incubated with potassium dichromate had a significantly greater mortality when compared to all the extracts and sea water $(\mathrm{P}<0.05)$. The ethanolic extract and sea water showed a mortality of $49.60 \%$ and $0 \%$ respectively. 


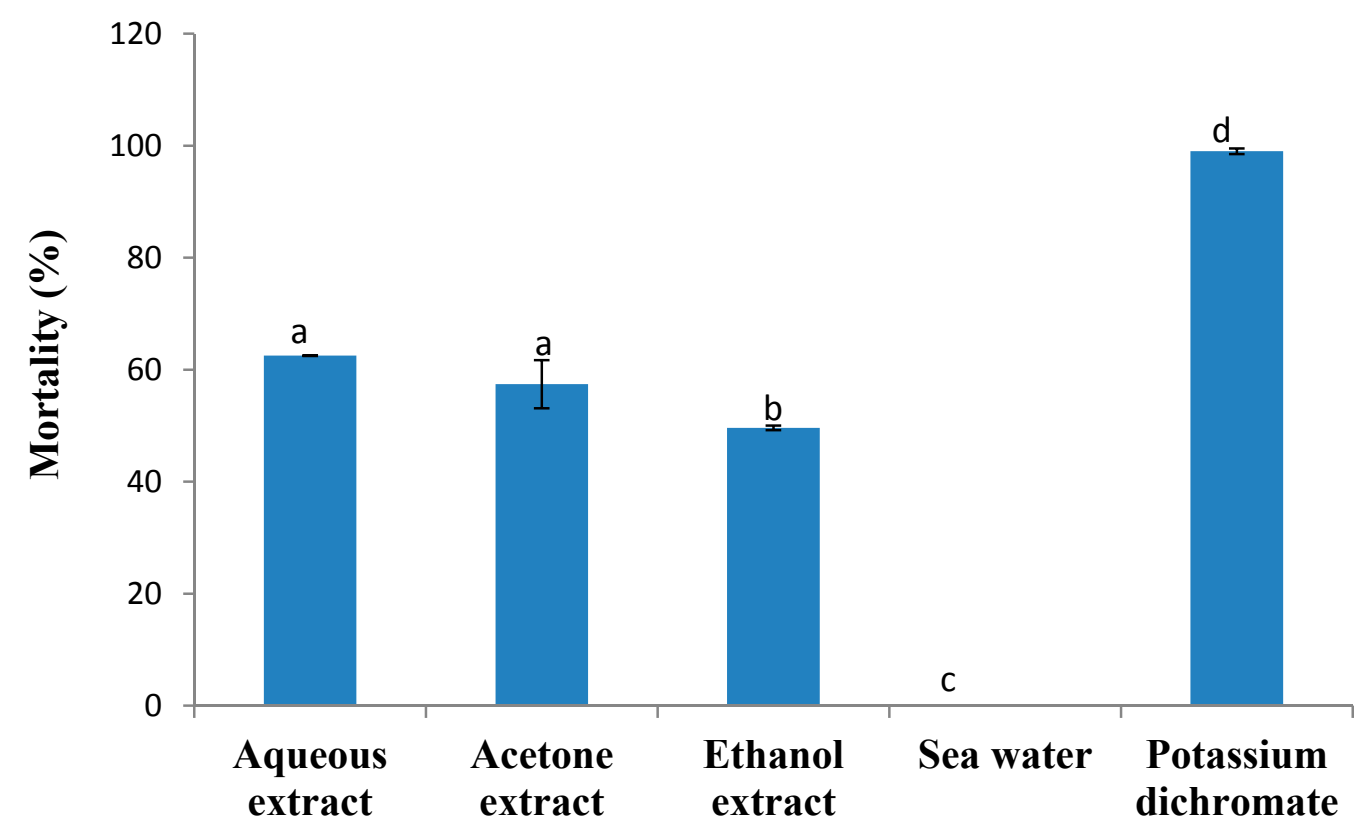

Figure 4: Percentage mortality of $A$. salina nauplii incubated in different plant extracts and controls.

*The values are means of five concentrations for each plant extract/control $\pm \mathrm{SD}$ of three replicates. Bars with different letters are significantly different $(\mathrm{P}<0.05)$.

The effect of different concentrations of the plant extracts on the mortality of larvae is shown in Figures 5. The degree of mortality of nauplii was in a concentration-dependent fashion. The highest mortality was observed in all the extracts at $1 \mathrm{mg} / \mathrm{mL}$ compared to potassium dichromate which showed maximum mortality $(100 \%)$ at $0.125 \mathrm{mg} / \mathrm{mL}$. There was no significant difference $(\mathrm{P}<0.05)$ in percentage mortality of the nauplii between the aqueous extract and acetone extract at concentrations of $0.125,0.25$ and $1 \mathrm{mg} / \mathrm{mL}$. At 0.125 and 0.5 $\mathrm{mg} / \mathrm{mL}$, aqueous and ethanol extracts also exhibited no significance difference in percentage mortality $(\mathrm{P}<0.05)$. At $1 \mathrm{mg} / \mathrm{mL}$, there was no significance difference in percentage mortality between aqueous and acetone extracts and also between the ethanolic extract and potassium dichromate $(\mathrm{P}<0.05)$ in Figure 5. The results revealed that the effect of varying concentrations of all the plant extracts on the mortality of larvae was in a concentration dependent fashion, therefore it can be postulated that though these are toxicological data, this plant possesses pharmacological activity based on the dosage administered [21, 32]. 


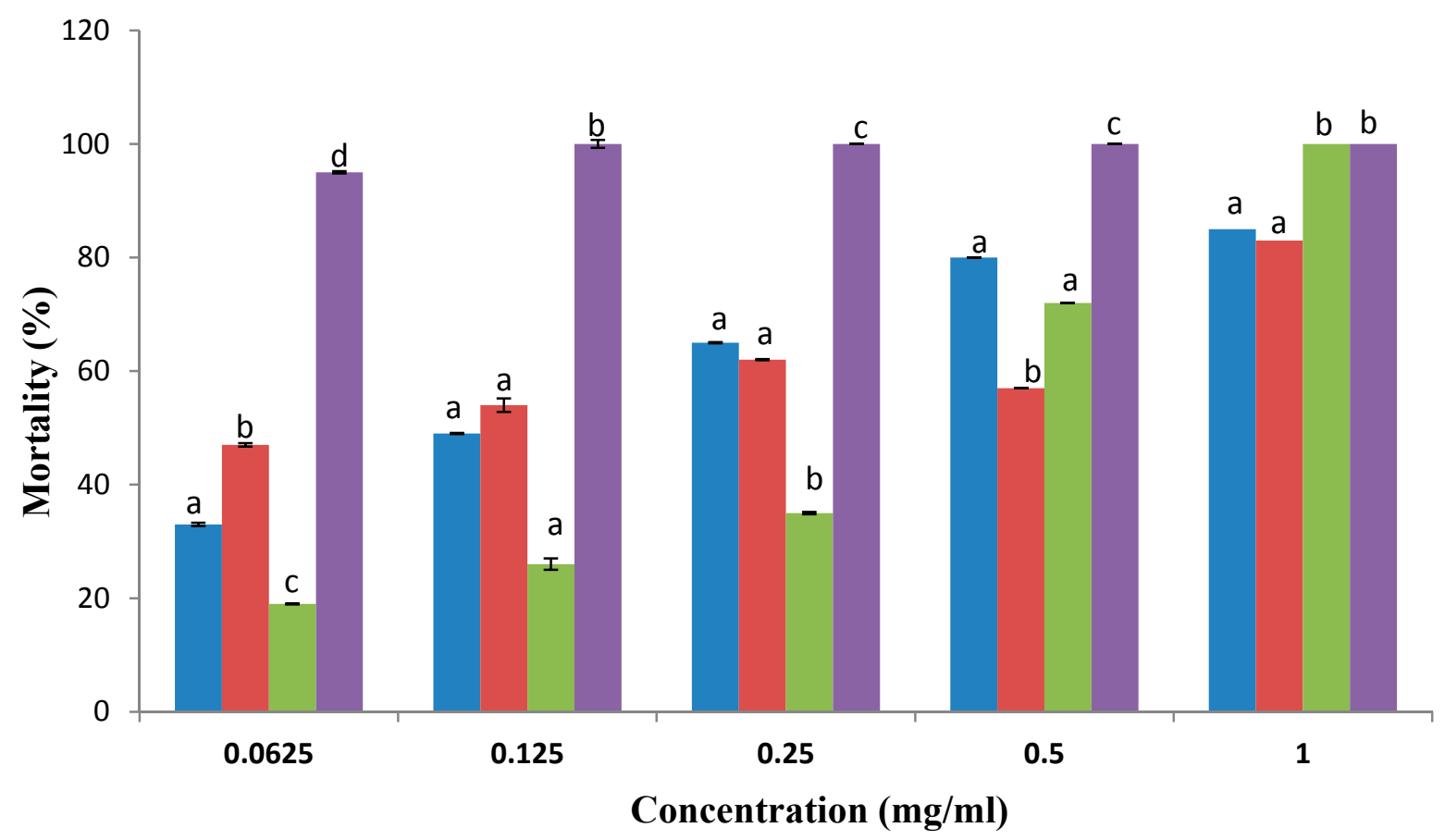

Aqueous extract $\quad$ Acetone extract $\square$ Ethanol extract $\square$ Potassium Dichromate

Figure 5: Percentage mortality of $A$. salina cysts incubated at different concentrations of the plant extracts and control.

*The values are means of three replicates \pm SD (at different hours). Set of bars with different letters are significantly different $(\mathrm{P}<0.05)$.

All extracts were screened at five different concentrations viz. 62.5, 125, 250, 500 and 1000 $\mu \mathrm{g} / \mathrm{mL}$ and observed for their toxic effect on A. salina from $24-72 \mathrm{~h}$. Potassium dichromate was used as a standard [33].

The percentage mortality due to exposure time is as shown in Figure 6. The result revealed that the percentage mortality was time dependent; the longer the exposure of nauplii to the plant extracts, the greater the mortality. It was observed that between 24-72 h of exposure of the nauphlii to aqueous, acetone and ethanol extracts, there was 2.94, 3.41 and 2.5-fold increase in the mortality of nauphlii respectively. The nauphlii incubated in sea water did not die throughout the duration of the experiment. Generally, the mortality of nauplii was significantly similar when incubated with the ethanol, acetone, and the aqueous extracts at 24 $\mathrm{h}$ and was significantly higher than sea water $(\mathrm{P}<0.05)$ (Figure 6$)$. The mortality of nauplii incubated in these plant extracts increased exponentially with time with the highest mortality observed at 72 hours with all the extracts. The nauplii attain the second and third instars of their life cycle within 48 hours hence reveal their greatest sensitivity to toxins at this time $[34,35]$. However, the findings of this study indicate that the maximum sensitivity was reached after 72 hours of exposure. 


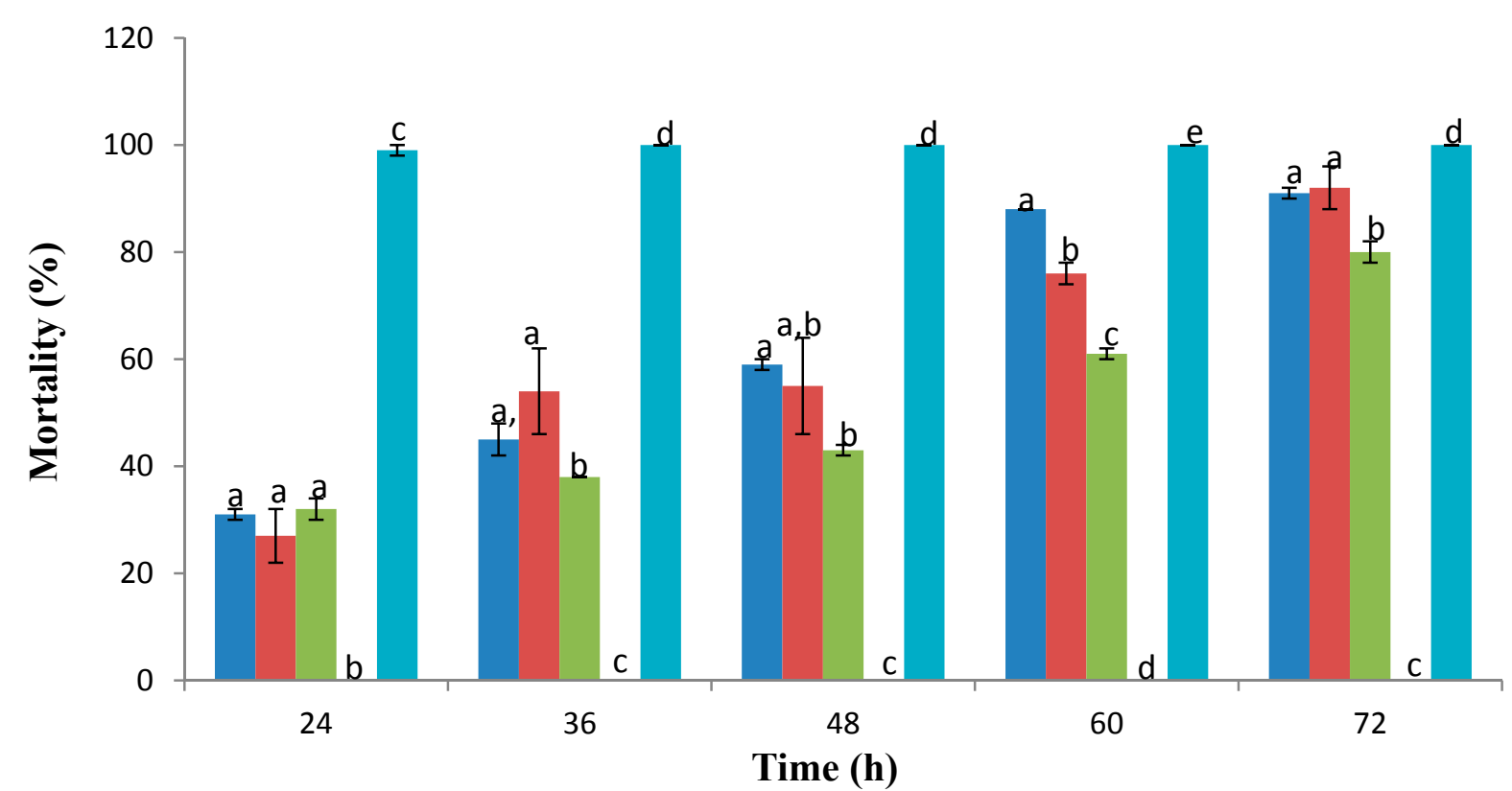

Aqueous extract $\square$ Acetone extract $\square$ Ethanol extract $\square$ Sea Water $\square$ Potassium dichromate

Figure 6: Percentage mortality of $A$. salina cysts incubated at different time durations in the plant extracts and controls.

*The values are means \pm SD of 3 replicates (of all the concentrations) for each plant extract/control $\pm \mathrm{SD}$. Set of bars with different letters are significantly different $(\mathrm{P}<0.05)$.

According to Meyer et al [13] and Bastos et al [36] the brine shrimp lethality were interpreted in accordance to the criterion by Meyer toxicity index that $\mathrm{LC}_{50}$ values greater than 1000 $\mu \mathrm{g} / \mathrm{mL}(1 \mathrm{mg} / \mathrm{mL})$ are considered non-toxic, LC 50 values equal $/$ greater than $500 \mu \mathrm{g} / \mathrm{mL}(0.5$ $\mathrm{mg} / \mathrm{mL}$ ) but not greater than $1000 \mu \mathrm{g} / \mathrm{mL}$ are considered to have weak toxicity while those having $\mathrm{LC}_{50}$ values less than $500 \mu \mathrm{g} / \mathrm{mL}$ are considered toxic. The $\mathrm{LC}_{50}$ values were calculated as $132 \mu \mathrm{g} / \mathrm{mL}$ for aqueous extract, $67.8 \mu \mathrm{g} / \mathrm{mL}$ for acetone extract and $383 \mu \mathrm{g} / \mathrm{mL}$ for the ethanol extracts, respectively (Table 1).

All of the crude extracts of $V$. mespilifolia were found to be lethal with $\mathrm{LC}_{50}<1 \mathrm{mg} / \mathrm{mL}$ (Table 1) and hence it could be employed as promising alternative in the treatment and management of tumor, as brine shrimp lethality test now serves as an indicator for the preliminary screening of bioactivity including for anticancer [37].

Table 1: Lethal dose concentration $\left(\mathrm{LC}_{50}\right)$ of acetone, ethanol and aqueous extracts of Vernonia mespilifolia against Brine Shrimp

\begin{tabular}{lllll}
\hline Sample & Regression equation & $\mathbf{L C}_{\mathbf{5 0}}(\boldsymbol{\mu g} / \mathbf{m L})$ & Toxicity status & $\mathbf{R}^{\mathbf{2}}(\%)$ \\
$\begin{array}{l}\text { Aqueous } \\
\text { extract }\end{array}$ & $\mathrm{Y}=19.476 \ln (\mathrm{x})+89.4$ & 132 & Toxic & 97.4 \\
$\begin{array}{l}\text { Acetone extract } \\
\text { Ethanol extract }\end{array}$ & $\mathrm{Y}=33.161 \mathrm{x}+47.75$ & 67.8 & Toxic & 85.8 \\
$\begin{array}{l}\text { Potassium } \\
\text { dichromate }\end{array}$ & $\mathrm{Y}=1.4427247 \ln (\mathrm{x})+101$ & $<0.100$ & Toxic & 96.3 \\
\hline
\end{tabular}

${ }^{*} \mathrm{LC}_{50}$ is the concentration $(\mu \mathrm{g} / \mathrm{mL})$ of the plant extracts and positive control (Potassium dichromate) sufficient to obtain $50 \%$ of inhibition of nauplii mortality of $A$. salina, respectively. $\mathrm{R}^{2}$ is the coefficient of determination of the regression equation. 


\subsection{Conclusion}

This study showed that the different crude extracts of Vernonia mespilifolia were lethal (LC50 $<1 \mathrm{mg} / \mathrm{mL}$ ) in the brine shrimp lethality assay. Further in vivo and in vitro studies with different human cell lines is required to ascertain the antitumor activity of this plant and also the isolation of the lead compound responsible for this activity, might be utilized for the development of novel anticancer drug.

Acknowledgments: The authors wish to acknowledge the financial support of National Research Foundation (NRF) (Grant No. 85294) and Govan Mbeki Research Development Centre, University of Fort Hare, South Africa.

Author Contributions: Jeremiah Oshiomame Unuofin, Gloria Aderonke Otunola and Anthony Jide Afolayan conceived and designed the experiments; Jeremiah Oshiomame Unuofin performed the experiments; Jeremiah Oshiomame Unuofin and Gloria Aderonke Otunola analyzed the data; Anthony Jide Afolayan contributed reagents/materials/analysis tools; Jeremiah Oshiomame Unuofin wrote the paper." Authorship must be limited to those who have contributed substantially to the work reported.

Conflicts of Interest: The authors declare no conflict of interest.

\section{References}

1. Robinson, H.; Funk, V.A. Gymnanthemum koekemoerae (Compositae, Vernonieae), a new species from South Africa. PhytoKeys 2014, 36, 59-65.

2. Raimondo, D., von Staden, L., Foden, W., Victor, J.E., Helme, N.A., Turner, R.C., Kamundi, D.A. and Manyama, P.A. Red List of South African Plants. Strelitzia 25. South African National Biodiversity Institute, Pretoria. 2009.

3. Afolayan, A.J.; Mbaebie, B.O. Ethnobotanical study of medicinal plants used as antiobesity remedies in Nkonkobe Municipality of South Africa. Phacog. Mag. 2010, 2, 11, 368-373.

4. Dold, A.P.; Cocks, M.L. Traditional veterinary medicine in the Alice district of the Eastern Cape Province, South Africa. S. Afr. J. Sci. 2001, 97, 375-379.

5. Farnsworth, N. R.; Soejarto, D. D. Global importance of medicinal plants. In: Akerele, O., Heywood, V., and Synge, H. (Eds.), The Conservation of Medicinal Plants. Cambridge University Press, Cambridge: 1991, 25-51.

6. Salim, A. A.; Chin, Y. W.; Kinghorn, A. D. Drug discovery from plants. Springer, Berlin, Heidelberg New York. 2005, p. 379.

7. Rasool Hassan, B. A. Medicinal plants (importance and uses). Pharmaceut. Anal. Acta 2012, 3, 139. http://dx.doi.org/10.4172/2153-2435.1000e139

8. Melanie, J. C. Herbal remedies: adverse effects and drug interactions. Am. Fam. Physician 1999, 59, 5, 1239-1244.

9. Parra, L.A.; Yhebra, R.S.; Sardiñas, I.G.; Buela, L.I. Comparative study of the assay of Artemia salina L. and the estimate of the medium lethal dose (LD50 value) in mice, to determine oral acute toxicity of plant extracts. Phytomed. 2001, 8, 395-400.

10. Firenzuoli, F.; Gori, L. Herbal medicine today: clinical and research issues. Evid. Based Complement. Alternat. Med. 2007, 4, 1, 37-40.

11. Mayorga, P.; Pérez, K.R.; Cruz, S.M.; Cáceres, A. Comparison of bioassays using the anostracan crustaceans Artemia salina and Thamnocephalus platyurus for plant extract toxicity screening. Bras. J. Pharm. 2010, 20, 897-903.

12. Pelka, M.; Danzl, C.; Distler, W.; Petschelt, A. A new screening test for toxicity testing of dental materials. J. Dent. 2000, 28, 341-345. 
13. Martínez, M.; Del Ramo, J.; Torreblanca, A.; Díaz-Mayans, J. Effect of cadmium exposure on zinc levels in the brine shrimp Artemia parthenogenetica. Aquaculture 1999, 172, 315- 325.

14. Kokkali, V.; Katramados, I.; Newman, J. D. Monitoring the effect of metal ions on the mobility of Artemia salina nauplii. Biosensors 2011, 1, 36-45.

15. Maurer-Jones, M.A., Love, S.A., Meierhofer, S., Marquis, B.J., Liu, Z., Haynes, C.L. Toxicity of nanoparticles to brine shrimp: An introduction to nanotoxicity and interdisciplinary science. J. Chem. Edu. 2013, 90, 475-478.

16. Carballo, J.L.; Hernández-Inda, Z.L.; Pérez, P.; García-Grávalos, M.D. A comparison between two brine shrimp assays to detect in vitro cytotoxicity in marine natural products. BMC Biotech. 2002, 2, 17-23.

17. Meyer, B.N.; Ferrigni, N.R.; Putnam, J.E.; Jacobsen, L.B.; Nichols, D.E.; McLaughlin, J.L. Brine Shrimp: A convenient general bioassay for active plant constituents. Planta Medica 1982, 45, 31-34.

18. McLaughlin, J.L.; Rogers, L.L.; Anderson, J.E. The use of biological assays to evaluate botanicals. Drug Inf. J. 1998, 32, 513-524.

19. Moshi, M.J.; Innocent, E.; Magadula, J.J.; Otieno, D.F.; Weisheit, A.; Mbabazi, P.K.; Nondo, R.S.O. Brine shrimp toxicity of some plants used as traditional medicines in Kagera Region, north western Tanzania. Tanz. J. H. Res. 2010, 12, 63-67.

20. Sharma, N.; Gupta, P.C.; Singh, A.; Rao, C.V. Brine shrimp Bioassay of Pentapetes phoenicea Linn. and Ipomoea carnea jacq. leaves. Der. Pharm. Lett. 2013, 5, 162167.

21. Otang, WM., Grierson, DS., Ndip, RN. Assessment of potential toxicity of three South African medicinal plants using the brine shrimp (Artemia salina) assay. Afr. J. Pharmacol. 2013, 7, 1272-79.

22. Adwan, K.; Abu-Hassan, N. Gentamicin resistance in clinical strains of enterobacteraceae associated with reduced gentamicin uptake. Fol. Microbiol. 1998, 43, 438-440.

23. Abu-Shanab, B.; Adwan, G.; Abu-Safiya, D.; Jarrar, N.; Adwan, K. Anti-bacterial activities of some plant extracts utilized in popular medicine in Palestine. Turk. $J$. Bio. 2004, 28, 99-102.

24. Sleet, R.B.; Brendel, K. Homogeneous populations of Artemia nauplii and their potential use for in vitro testing in developmental toxicology. Teratog. Carcinog. Mutagen 1985, 5, 41-54.

25. Lewan, L.; Andersson, M.; Morales, P.G. The use of Artemia salina in toxicity. Testing Alternatives Lab. Anim. 1992, 20, 297-301.

26. Vasconcelos, V.; Azevedo, J.; Silva, M.; Ramos, V. Effects of marine toxins on the reproduction and early stages development of aquatic organisms. Mar. Drugs 2010, 8, 59-79.

27. Subhadra, S.; Kanacharalapalli, V.R.; Rivindran, V.K.; Parre, S.K.; Chintala, S.; Thatipally, R. Comparative toxicity assessment of three Tephrosia species on Artemisia salina and animal cell lines. J. Nat. Pharm. 2011, 3, 143-148.

28. Solis, P.N.C., Wright, W., Anderson, M.M., Gupta, M.P., Phillison, J.D. A microwell cytotoxicity assay using Artemia salina. Planta Medica 1993, 59, 50 - 252.

29. Jaki, B.; Burji, H.R.; Stich-er, O. Biological Screening of cyanobacteria for antimicrobial and molluscidal activity, brine shrimp lethality, and cytotoxicity. Pharm. Biol. 1999, 37, 138-143.

30. Piccardi, R.; Frosini, A.; Tredici, M. R.; Margheri, M. C. Bioactivity in freeliving and symbiotic cyanobacteria of the genus Nostoc. J. Appl. Phycol. 2000, 12, 543547. 
31. Lahti, K.; Ahtiainen, J.; Rapala, J.; Sivonen, K.; Niemelä, S.I. Assessment of rapid bioassays for detecting cyanobacterial toxicity. Lett. appl. Microbiol. 1995, 21, 109114.

32. Kibiti, C.M.; Afolayan, A.J. Antifungal activity and brine shrimp toxicity assessment of Bulbine abyssinica used in the folk medicine in the Eastern Cape Province, South Africa. Bangladesh J. Pharmacol. 2016, 11, 469-477.

33. Padmaja, R.; Arun, P.C.; Prashanth, D.; Deepak, M.; Amita, A., Anjana, M. Brine shrimp lethality bioassay of selected Indian medicinal plants. Fitoterapia 2002, 73, 508-510.

34. Lewis, G.E.; Testing the toxicity of extracts of Southern African plants using brine shrimp (Artemia salina). S. Afr. J. Sci. 1995, 91, 382-390.

35. Sreejamole, K.L; Radhakrishnan, C.K. Antioxidant and cytotoxic activities of ethyl acetate extract of the Indian green mussel Perna viridis. Asian J. Pharm. Clin. Res. 2013, 6, 197-201.

36. Bastos, M.L.A.; Lima, M.R.F.; Conserva, L.M., Andrade, V.S., Rocha, E.M.M., Lemos, R.P.L. Studies on the antimicrobial activity and brine shrimp toxicity of Zeyheria tuberculosa (Vell.) Bur. (Bignoniaceae) extracts and their main constituents. Annals Clinical Microbiology and Antimicrobials 2009, 8, 16. DOI: 10.1186/1476.

37. Artanti, N.; Firmansyah, T.; Darmawan, A. Bioactivities evaluation of Indonesian mistletoe (Dendropthoe pentandra (L.) Miq.) leaves extracts, J. Applied Pharm. Sci., 2012, 1, 24-27.

(C) 2016 by the authors; licensee Preprints, Basel, Switzerland. This article is an open access article distributed under the terms and conditions of the Creative Commons by Attribution (CC-BY) license (http://creativecommons.org/licenses/by/4.0/). 